\title{
Chemical Water Types of Unconfined Groundwater in Southern Bandung
}

\author{
Wilda Naily ${ }^{1,2}$, Hendarmawan ${ }^{3}$ \\ \{wilda.naily@gmail.com, hendarmawan@mail.unpad.ac.id\} \\ Environmental Science, Postgraduate School Universitas Padjadjaran, Jl Dipatiukur Bandung 1,3 \\ Research Center for Geotechnologi LIPI, Jl Sangkuriang Bandung ${ }^{2}$
}

\begin{abstract}
Groundwater provides an overview of environmental conditions in an area. Chemical analysis of groundwater will provide information about the origin and quality of groundwater as a basis for groundwater utilization. In this paper, analysis is carried out by determining the water types of unconfined groundwater. An unconfined groundwater sample was taken from Southern Bandung. Measurement of major ion (sodium, potassium, magnesium, calcium, chloride, sulfate and bicarbonate), also $\mathrm{pH}$ and electrical conductivity were carried out in 16 groundwater samples. Paper discusses a) the classification of groundwater types determined by the Kurlov method, b) the correlation of chemical properties in groundwater determined by the Stiff method. The result showed that unconfined groundwater in Southern Bandung was dominated by calcium cations and bicarbonate anions, and water type was dominated by calcium - alkali - bicarbonate chloride. The correlation of chemical properties in groundwater is seen in several locations that show groundwater in the same flow and is fresh.
\end{abstract}

Keywords: Groundwater, water type, major ion, calcium, bicarbonate.

\section{Introduction}

Chemical content in water consists of ions (anions and cations). Based on concentration, ions in water are divided into major ions $(1-1000 \mathrm{mg} / \mathrm{L})$ and minor ions $(0.01-10 \mathrm{mg} / \mathrm{L})[1,2]$. The presence of major ions can affect water types, while minor ions are not very influential. Minor ions affect others in water such as nitrates on health. Water types are a description of the amount of ion concentration in water that can determine the nature of groundwater, and provides an overview of environmental conditions.

The interpretation of groundwater chemistry can be solved by several methods, among which are the Kurlov and Stiff method. Kurlov is a classification method to determine the groundwater water types by calculating the percentage of milliequivalent anions and cations in groundwater using Kurlov formula, determination of water type is based on ion content which $\geq 25 \%$ [3]. Stiff is a correlation method to determine groundwater water types and also shows the differences and similarities in the pattern, in units of $\mathrm{mg} / \mathrm{L}$ or meq/L. This method uses a horizontal parallel axis and a vertical axis to compare chemical composition based on the direction of flow. The cation is plotted at the top from zero and the anion is at the bottom of zero. The relationship between cations points and anion points gives a pattern, different patterns show different water types. The pattern that results can be interpreted as the development of these ions in the groundwater [3]. 
Southern Bandung is predicted to develop rapidly along with the construction of new toll roads, its interesting to see groundwater in the region, especially unconfined groundwater which is widely used as a water source and vulnerable to change. Chemical analysis of groundwater content will provide information about the origin and quality of groundwater as a basis for groundwater utilization.

\section{Study Area}

The study was conducted in Southern Bandung, and 16 samples of unconfined groundwater were taken. Spread in Banjaran District, Pangalengan District, Ciparay District, Rancaekek District, Margahayu District, and Margaasih District, see Figure 1. Topographically, the study area is mostly mountainous or hilly and partly terrain. The constituent rocks of the study area are sand, clay sand, and medium sand, see Figure 2.

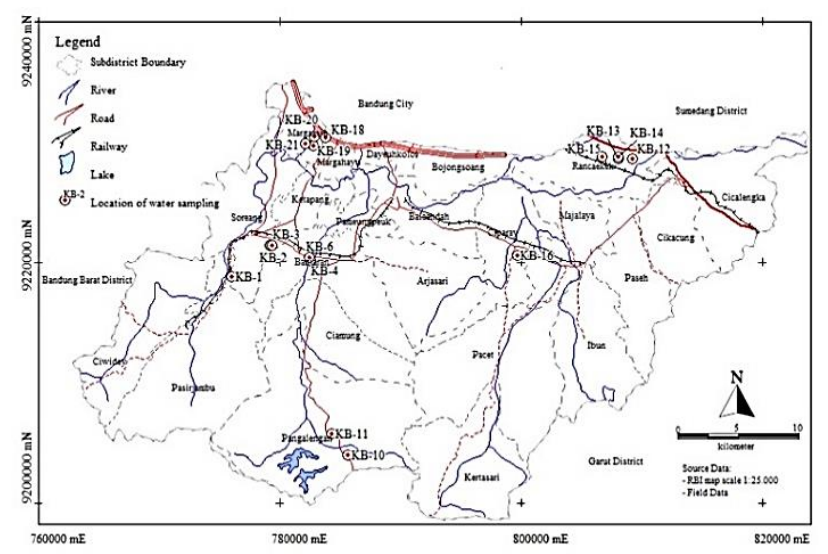

Fig. 1. Location of the study area.

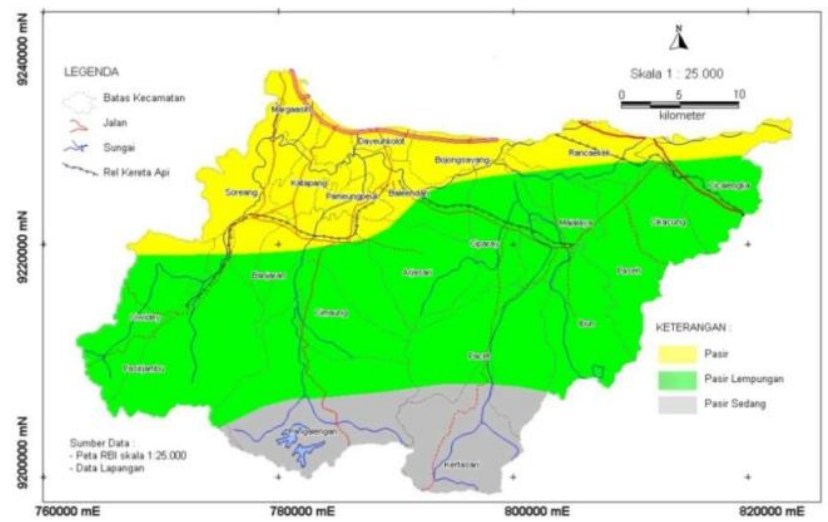

Fig. 2. The type of rock at study area [4]. 


\section{Methodology}

Chemical water types are determined from the major ions in water, consisting of cations (sodium, potassium, magnesium, calcium), and anions (chloride, sulfate, and bicarbonate). In addition, the parameters of $\mathrm{pH}$ and electrical conductivity were also determined. Groundwater samples were taken are unconfined groundwater from residents dug wells, and preserved in ice boxes filled with ice, then analyzed in a laboratory. The water chemistry analysis examination method is in accordance with the analysis method in Table 1.

Table 1. Analytical methods for examining water samples.

\begin{tabular}{llll}
\hline No & Parameter & Preservation & Methode [5] \\
\hline 1 & pH & & Potentiometry \\
2 & Electrical conductivity & & Conductometry \\
3 & Sodium $\left(\mathrm{Na}^{+}\right)$ & Decrased & Flame Photometry \\
4 & Potassium $\left(\mathrm{K}^{+}\right)$ & temperature & Flame Photometry \\
5 & Magnesium $\left(\mathrm{Mg}^{2+}\right)$ & of water & Complexometry-Volumetric \\
6 & Calcium $\left(\mathrm{Ca}^{2+}\right)$ & samples & Complexometry-Volumetric \\
7 & Chloride $\left(\mathrm{Cl}^{-}\right)$ & until it reaches & Argentometry- Volumetric \\
8 & Sulfate $\left(\mathrm{SO}_{4}^{-}\right)$ & around $10^{\circ} \mathrm{C}$ & Turbidimetry- Spectrophotometry \\
9 & Bicarbonate $\left(\mathrm{HCO}_{3}^{-}\right)$ & & Acidimetry- Volumetric \\
\hline
\end{tabular}

Parameters analysis in Table 1 is used to determine water type by Kurlov method. Anions and cations respectively as numerator and denominator, the number of anions and cations in the unit of meq/L, only ions which amount more than $25 \%$ of total meq/L will have a significant effect on water type. Characteristic constituents or properties of water, such as $\mathrm{pH}$ are following the fraction, see equation (1).

$$
\frac{\text { anions }}{\text { cations }} \text { water characteristic }=\frac{\mathrm{Cl}_{x} \mathrm{HCO}_{3} \mathrm{SO}_{4 x}}{\mathrm{Ca}_{x} \mathrm{Mg} g_{x} \mathrm{Na}+K_{x}} p H_{x} \ldots
$$

The stiff method is carried out using Plotchem. The plot of anions and cations will produce various patterns, depending on the number of ions in water. The shape of the pattern will indicate water types, different patterns show the different water types, while the size of the pattern indicates the number of ions contained in the groundwater.

\section{Result and Discussion}

The acidity or basicity of a solution is determined by the presence of hydrogen ions in water called $\mathrm{pH}$. The neutral solution is a solution that has a $\mathrm{pH}$ of 7 . The water sample at the study area has a $\mathrm{pH}$ of $5.42-7.46$, dominantly the water sample has a neutral $\mathrm{pH}$ and some are slightly acidic as shown in Figure 3.

Electrical conductivity provides information about the nature of water. Based on the classification conducted by Mandel [6], the distribution of water based on electrical conductivity is distilled water, rainwater, fresh groundwater, seawater, and saltwater. Fresh groundwater has 
an electrical conductivity value of $30-2000 \mu \mathrm{S}$ [6]. The water sample at the study area has an electrical conductivity value of $149-1020 \mu \mathrm{S} / \mathrm{cm}$ or is fresh groundwater, see Figure 3.

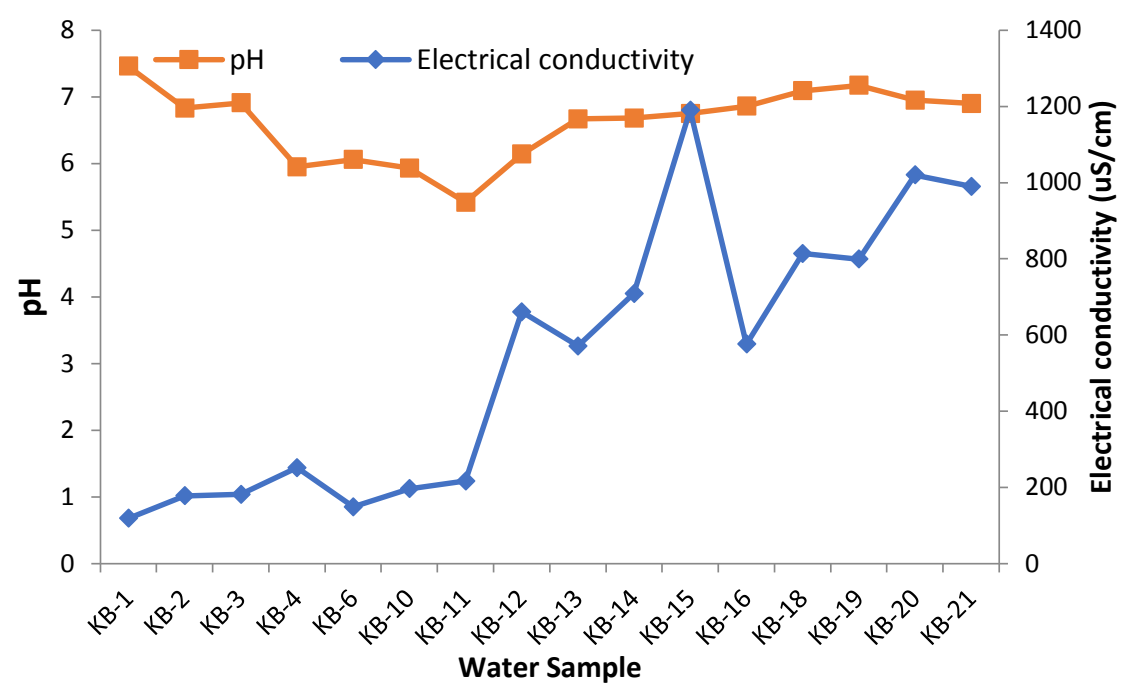

Fig 3. $\mathrm{pH}$ and electrical conductivity at the study area.

The analysis of determining water types using the Kurlov method and Stiff method. The data used is data with a maximum ion balance error of 5\% [1]. Determination of ion balance error using equation (2).

$$
E=\frac{r c-r a}{r c+r a} X 100 \%
$$

Where $\mathrm{E}=$ ion balance error

$\mathrm{ra}=$ number of anions in units $\mathrm{meq} / \mathrm{L}$

$\mathrm{rc}=$ number ofc anions in units $\mathrm{meq} / \mathrm{L}$

The analysis of water types determination using the Kurlov method is shown in Figure 4. While Figure 4 shows a resume of Kurlov method analysis. Based on Table 2, the dominant water types at the study area are Calcium - Alkali - Bicarbonate - Chloride, found in 6 water sample locations, that are Rancaekek District, Ciparay District, and Margaasih District. The dominant cation in the water sample is calcium cation, and the dominant anion in the water sample is bicarbonate anion. Calcium cation and bicarbonate anion are ions that form freshwater, bound to form water type calcium bicarbonate $[1,2,7,8]$, as shown in equation (3).

$$
\mathrm{Ca}^{2+}+\mathrm{HCO}_{3}{ }^{2-}==>\mathrm{Ca}\left(\mathrm{HCO}_{3}\right)_{2}
$$

The presence of this water type shows that groundwater in the study area has not been disturbed, although unconfined groundwater is very susceptible to contamination because it is close to the 
ground surface. The ion content in groundwater is influenced by rocks where groundwater exists.

Alkaline cations, sulfate anions, and chloride anions are found in dominant quantities in several locations. The discovery of these ions shows that groundwater begins to change even in small concentrations, but this can be an indication of the risk of pollution. Based on field observations, water samples that have an alkaline cation and a sulfate anion or chloride anion are dominantly adjacent to a septic tank or gutter, so that possible ion differences can occur due to anthropogenic influences and its local.

\begin{tabular}{|c|c|c|c|c|c|c|c|c|c|c|c|c|c|}
\hline \multirow{2}{*}{\multicolumn{2}{|c|}{$\begin{array}{l}\text { Chemical } \\
\text { Analysis }\end{array}$}} & \multicolumn{3}{|c|}{ KB1 } & \multicolumn{3}{|c|}{ KB2 } & \multicolumn{3}{|c|}{ KB3 } & \multicolumn{3}{|c|}{ KB4 } \\
\hline & & $\mathrm{mg} / \mathrm{l}$ & $\mathrm{meq} / 1$ & meq $\%$ & $\mathrm{mg} / \mathrm{l}$ & $\mathrm{meq} / \mathrm{l}$ & meq $\%$ & $\mathrm{mg} / \mathrm{l}$ & $\mathrm{meq} / 1$ & $\mathrm{meq} \%$ & $\mathrm{mg} / \mathrm{l}$ & $\mathrm{meq} / 1$ & $\mathrm{meq} \%$ \\
\hline \multirow{7}{*}{ है } & $\mathrm{Na}^{+}$ & 14.600 & 0.635 & 38.958 & 13.450 & 0.585 & 38.408 & 7.710 & 0.335 & 20.341 & 23.790 & 1.035 & 41.527 \\
\hline & $\mathrm{K}^{+}$ & 1.520 & 0.039 & 2.385 & 5.180 & 0.133 & 8.698 & 3.350 & 0.086 & 5.197 & 6.100 & 0.156 & 6.261 \\
\hline & $\mathrm{Ca}^{2+}$ & 9.650 & 0.482 & 29.538 & 9.650 & 0.482 & 31.611 & 14.470 & 0.722 & 43.792 & 16.080 & 0.802 & 32.198 \\
\hline & $\mathrm{Mg}^{2+}$ & 5.670 & 0.467 & 28.621 & 3.910 & 0.322 & 21.122 & 5.870 & 0.483 & 29.296 & 5.870 & 0.483 & 19.383 \\
\hline & $\mathrm{Fe}^{2+}$ & 0.178 & 0.006 & 0.391 & 0.044 & 0.002 & 0.103 & 0.213 & 0.008 & 0.463 & 0.056 & 0.002 & 0.080 \\
\hline & $\mathrm{Mn}^{2+}$ & 0.048 & 0.002 & 0.107 & 0.024 & 0.001 & 0.057 & 0.413 & 0.015 & 0.912 & 0.376 & 0.014 & 0.549 \\
\hline & $\Sigma$ & & 1.630 & 100.000 & - & 1.523 & 100.000 & - & 1.649 & 100.000 & - & 2.492 & 100.000 \\
\hline \multirow{5}{*}{ 簖 } & $\mathrm{HCO}_{3}^{-}$ & 57.490 & 0.942 & 57.688 & 35.020 & 0.574 & 37.615 & 63.080 & 1.034 & 60.161 & 51.490 & 0.844 & 32.595 \\
\hline & $\mathrm{SO}_{4}^{2-}$ & 19.500 & 0.406 & 24.868 & 3.900 & 0.081 & 5.324 & 12.400 & 0.258 & 15.030 & 14.500 & 0.302 & 11.666 \\
\hline & $\mathrm{Cl}^{-}$ & 9.340 & 0.263 & 16.131 & 28.030 & 0.791 & 51.819 & 14.010 & 0.395 & 22.998 & 46.720 & 1.318 & 50.905 \\
\hline & $\mathrm{NO}_{3}^{-}$ & 1.330 & 0.021 & 1.313 & 4.960 & 0.080 & 5.243 & 1.930 & 0.031 & 1.811 & 7.760 & 0.125 & 4.834 \\
\hline & $\Sigma$ & & 1.633 & 100.000 & 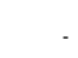 & 1.526 & 100.000 & -1 & 1.719 & 100.000 & . & 2.589 & 100.000 \\
\hline \multicolumn{2}{|c|}{$\begin{array}{l}\text { Kurlov } \\
\text { Formula }\end{array}$} & \multicolumn{3}{|c|}{$\frac{\mathrm{HCO}_{358} \mathrm{SO}_{425} \mathrm{Cl}_{16}}{\mathrm{Na}+K_{41} \mathrm{Ca}_{30} \mathrm{Mg}_{29}}$} & \multicolumn{3}{|c|}{$\frac{\mathrm{Cl}_{52} \mathrm{HCO}_{338} \mathrm{SO}_{45}}{\mathrm{Na}+K_{47} \mathrm{Ca}_{32} \mathrm{Mg}_{21}}$} & \multicolumn{3}{|c|}{$\frac{\mathrm{HCO}_{360} \mathrm{Cl}_{23} \mathrm{SO}_{415}}{\mathrm{Ca}_{44} \mathrm{Mg} \mathrm{g}_{29} \mathrm{Na}+\mathrm{K}_{25}}$} & \multicolumn{3}{|c|}{$\frac{\mathrm{Cl}_{51} \mathrm{HCO}_{332} \mathrm{SO}_{419}}{\mathrm{Na}+K_{48} \mathrm{Ca}_{32} \mathrm{Mg}_{19}}$} \\
\hline \multicolumn{2}{|c|}{$\begin{array}{l}\text { Type of } \\
\text { Water }\end{array}$} & \multicolumn{3}{|c|}{$\begin{array}{l}\text { Alkali - Calcium - Magnesium - } \\
\text { Bicarbonat - Sulfat }\end{array}$} & \multicolumn{3}{|c|}{$\begin{array}{l}\text { Alkali - Calcium - Klorida - } \\
\text { Bicarbonat }\end{array}$} & \multicolumn{3}{|c|}{ Calcium - Magnesium - Bicarbonat } & \multicolumn{3}{|c|}{$\begin{array}{l}\text { Alkali - Calcium - Klorida - } \\
\text { Bicarbonat }\end{array}$} \\
\hline
\end{tabular}

Fig. 4. Determination of water types with Kurlov Method.

Table 2. Summary of Kurlov Methode.

\begin{tabular}{llll}
\hline No & Water type & Sample No \\
\hline 1 & Calcium - Alkali - Bicarbonat - Klorida & KB12, & KB13, \\
& & KB14, KB16, \\
& & KB18, KB21 \\
2 & Alkali -Calcium - Bikarbonat - Klorida & KB19, KB20 \\
3 & Alkali - Calcium - Sulfat - Bicarbonat & KB15 \\
4 & Calcium - Magnesium - Alkali - Klorida & KB11 \\
5 & Calcium - Magnesium - Bicarbonat -Klorida & KB10 \\
6 & Calcium - Magnesium - Klorida - Bicarbonat & KB6 \\
7 & Alkali - Calcium - Klorida - Bicarbonat & KB2, KB4 \\
8 & Calcium - Magnesium - Bicarbonat & KB3 \\
9 & Alkali - Calcium - Magnesium - Bicarbonat - Sulfat & KB1 \\
\hline
\end{tabular}

The analysis of determining water types using the Stiff method is shown in Figure 5 and Figure 6. The results of the Stiff method are patterns that describe water types, the same pattern besides describing the same water types, also means that groundwater samples are in the same flow.

Figure 5 showed that groundwater samples from KB12, KB13, KB14, KB16, KB18, $\mathrm{KB} 19$, KB20, and KB21 have the same pattern shape of Stiff method, the ions content is 
dominated by calcium cation and bicarbonate anion. The same Stiff pattern shows that groundwater samples are in the same flow. The water samples are in Rancaekek District, Ciparay District, and Margahayu District.

In Figure 6, the water samples in KB2 and KB4 have the same pattern shape as the Stiff method, this indicates that groundwater is in the same flow. The dominant ion content of the water sample in the Banjaran District is alkali cation.

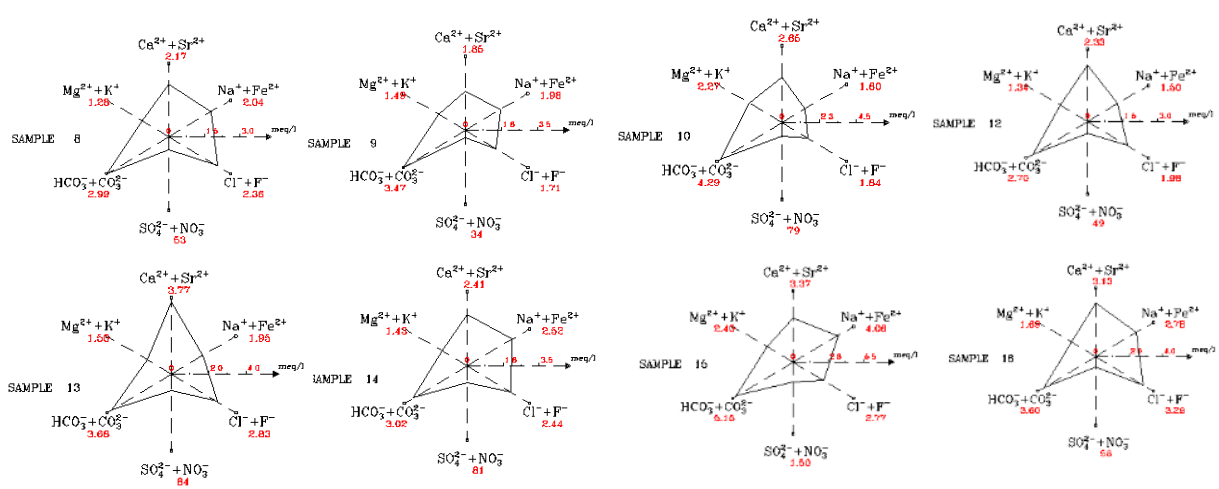

Fig 5. The pattern of the Stiff method with a predominance of cation calcium.
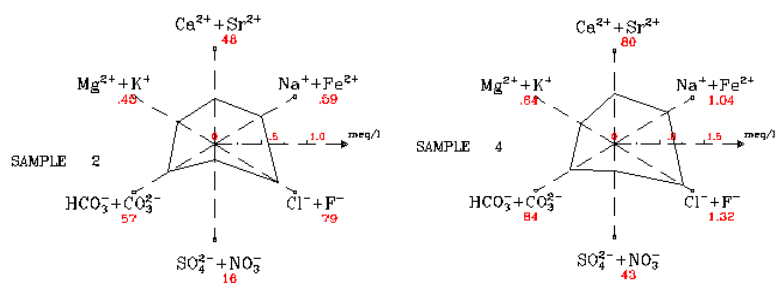

Fig 6. The pattern of the Stiff method with the predominance of cation alkali.

\section{Conclusion}

Analysis by Kurlov method shows that unconfined groundwater in Southern Bandung is dominated by cations calcium and anions bicarbonate, and water type is dominated by calcium - alkali - bicarbonate - chloride. Analysis by Stiff method shows that the correlation of groundwater chemical content is seen in several locations which show groundwater is in the same flow and is fresh nature. 


\section{References}

[1] Matthess, G: The Properties of Groundwater. Department of Environmental Science, John Wiley and Sons Inc., New York. pp. 406 (1982)

[2] Tood, D. K: Groundwater Hydrology. John Wiley and Sons Inc, New York (1980)

[3] Zaporozec, A: Graphical Interpretation of Water-Quality Data. Vol. 10, N0. 2, pp. 32-43. Groundwater (1972)

[4] Maris, R., Rusydi, A. N., Naily, W., : Potensi Pencemaran Airtanah di Daerah Sub Urban Kabupaten Bandung Bagian Selatan dengan Menggunakan Metode LeGrand, Pp. 233-242. Proceeding Seminar Nasional Kebumian Ke-10 (2017)

[5] Eaton, A.D., L.S. Clesceri, E.W. Rice, A.E. Greenberg, M.A.H. Franson (editors): Standard Methods for the Examination of Water and Wastewater, Centenial Edition, 21th edition, American Public Health Association, Washington, D. C., pp. 1368 (2005)

[6] Mandel, S., and Shiftan, Z., L: Groundwater Resources: Investigation and Development, Academic Press, New York (1981)

[7] Anthoni, J. F: The Chemical Composition of Seawater, ww.searchfriends.org.n /oceano/seawater.htm. Download 2016, Februari (2006)

[8] Naily, W., Sudaryanto, Suherman, D: Pengaruh Air Laut pada Airtanah Tidak Tertekan di Wilayah Utara Kota dan Kabupaten Serang, Provinsi Banten, Riset Geologi dan Pertambangan Vol.26, No 2pp 101-105 (2016) 